\title{
A Novel Locally Prepared Inactivated Bivalent Mycoplasma Vaccine for Chicken Flocks in Egypt
}

\section{Muhammed Saeed El-Naggar ${ }^{1}$, Hazem Mohammed Ibrahim², Heba Mohammed Salem ${ }^{3}$, Sherif Marouf*}

${ }^{1}$ Post-graduate student, Microbiology Department, Faculty of Veterinary Medicine, Cairo University, Egypt; ${ }^{2}$ Veterinary Serum and Vaccine Research Institute, Agricultural Research Center, Egypt; ${ }^{3}$ Poultry diseases Department, Faculty of Veterinary Medicine, Cairo University, Egypt; ${ }^{4}$ Microbiology Department, Faculty of Veterinary Medicine, Cairo University, Egypt.

\begin{abstract}
Mycoplasma is a vertically transmitted disease causing severe economic losses in poultry industry, so this study aimed to prepare a local inactivated a bivalent Mycoplasma gallisepticum (MG) and Mycoplasma synoviae (MS) vaccine. Vaccine was adjuvanted with Montanide ISA70 then evaluated for safety, sterility, and potency. The vaccine efficacy was evaluated in $50 \mathrm{SPF}$ one day old chicks which divided into 5 groups 10 birds each. Chicks were vaccinated with $1^{\text {st }}$ dose at 7 days of age and boostered with the $2^{\text {nd }}$ dose after 3 weeks. Three weeks post vaccination with $2^{\text {nd }}$ dose birds were challenged, chicks were kept under observations for 10 weeks. During the experiment data of clinical signs, daily mortality, body weight, postmortem, serum samples and nasal swabs were collected. serum samples were collected weekly after first vaccination till the third week after challenge and humoral immune response was estimated against Mycoplasma strains using the enzyme-linked immunosorbent assay (ELISA) test and results revealed that vaccines gave a high protective antibody titer, and the vaccine gave $80 \%$ protection against MG and $90 \%$ against MS. From our result locally prepared inactivated bivalent vaccine gave a promising result in birds protection against serious avian pathogens and considered as an effective tool for the prevention of mycoplasmosis in layers and breeders chicken farms in Egypt.
\end{abstract}

Keywords | Chicken, Mycoplasma gallisepticum, Mycoplasma synoviae, Inactivated vaccine, Poultry, Montanide oil adjuvant

Received | August 22, 2021; Accepted | September 26, 2021; Published | December 01, 2021

${ }^{*}$ Correspondence | Sherif Marouf, A novel locally prepared inactivated bivalent Mycoplasma vaccine for chicken flocks in Egypt; Email: dr.sherif.marouf@gmail. com

Citation | El-Naggar MS, Ibrahim HM, Salem HM, Marouf S (2022). A novel locally prepared inactivated bivalent mycoplasma vaccine for chicken flocks in Egypt. Adv. Anim. Vet. Sci. 10(1): 55-61.

DOI | http://dx.doi.org/10.17582/journal.aavs/2022/10.1.55.61

ISSN (Online) | 2307-8316; ISSN (Print) | 2309-3331

Copyright (c) 2022 El-Naggar et al. This is an open access article distributed under the Creative Commons Attribution License, which permits unrestricted use, distribution, and reproduction in any medium, provided the original work is properly cited.

\section{INTRODUCTION}

$\mathrm{I}$ $\mathrm{n}$ the poultry business, MG and MS cause a significant economic loss, notably in chickens and turkeys a cross the world, and is linked to respiratory illnesses, poor performance, decreased egg production, lowered fertility, and increased embryonic mortalities (Eissa et al., 2014; Marouf et al., 2020; El-Ashram et al., 2021). Mycoplasmas are tiny prokaryotes with a diameter of $300-800 \mathrm{~nm}$, they don't have a cell wall, but have a triple-layered plasma membrane that surrounds them, slow-growing, relatively fastidious organisms with a typical growth temperature of $37^{\circ} \mathrm{C}$, it can infect people, birds and animals (Razin et al., 1998; Brown et al., 2007). In chickens, MG is a harmful and commercially significant pathogen, vertically and horizontally transmitted disease, and the Office International des Epizootics (OIE) has deemed MGrelated sickness to be notifiable (OIE, 2004). The illness is usually recognized as chronic respiratory disease (CRD) in chickens and infectious sinusitis in turkeys (Levisohn 
and Kleven, 2000; Ley, 2008) reducing carcass quality, and making sick birds vulnerable to additional infections (Beaudet et al., 2017; Ishfaq et al., 2019) Mycoplasma synoviae is significant pathogen that infect birds' joints, bones, and respiratory systems. Infection is known as Infectious Synovitis and Arthritis that spread all over the world. It is economically significant because infection can affect egg production (Kleven, 2003). Although asymptomatic infections are prevalent, MG causes respiratory illness and synovitis in developing birds. MS is found in commercial layer flocks of various ages with a little effect on egg production (Whithear, 1996) as well as MS provoked variable postmortem lesions that appears in shape of hepatosplenomegaly with mottled necrosis, enlarged kidneys, presence of creamy to grey exudate in the joint and along tendon sheaths (Kleven, 2003). For the diagnosis of avian mycoplasmosis, after isolation in mycoplasma medium, immunological techniques or DNA detection in field samples or cultures can be used to identify MG and MS. In specialist laboratories, PCR-based DNA detection techniques are employed. They can be utilized on swab material or cultures once they've been verified. To identify MG or MS antibodies, a variety of serological assays are performed. The rapid serum agglutination (RSA) test, the enzyme-linked immunosorbent assay (ELISA), and the hemagglutination inhibition (HI) tests are the most often employed. There are several commercial MG and MS antibody ELISA kits on the market (Bekele and Assefa, 2018; Elyazeed et al., 2020). According to the previous studies, vaccination is the sole option for controlling mycoplasmosis in hens, side by side with biosecurity and sound management practices must be considered. Vaccination, as an interim step toward eradication, may be the most practicable strategy in endemically infested multi-age commercial layer operations (Branton et al.,1988; Kleven et al., 1984; Kleven, 2008). Despite substantial study into the pathology of MG, there are various obstacles to vaccines being successful in preventing MG infection due to the presence of many challenges as; colonization of $\mathrm{MG}$ in the respiratory tract of the host, presence of co-infection, bird immune status, phase or antigenic variation that led to immune escape from the host immune system, horizontal and vertical transmission of infection in the flocks (Beaudet et al., 2017,2019). There are many previous studies have focused on live attenuated vaccine, killed vaccines (bacterin-based) or recombinant proteins (Whithear, 1996; Hussein et al., 2007; Rabie and Girh, 2020). Adler et al. (1960) proposed vaccination against mycoplasma infections in chicken for the first time then, Fabricant (1975), followed by Luginbuhl et al. (1967) who applicated it on field level. Later, many types of $\mathrm{MG}$ vaccines have been available to overcome $\mathrm{MG}$ and the existing co-infections in from of live attenuated vaccines as (6/85 strain, ts-11, $F$ strain, $K$ strain and
K5054); attenuated and genetically modified MG vaccine GT5 recombinant fowl pox virus encoding genes for MG; recombinant adenovirus containing the TM- 1 protein of MG (pBH-S1-TM-1-EGFP) and S1 spike glycoprotein of infectious bronchitis virus, recombinant bivalent $\mathrm{pBH}-$ S1-TM-1-EGFP adenovirus, these vaccines applied through spray or eye drop method although, some of them produce a protective immunity against MG but they may produce lesions in immune suppressed flocks especially with the presence of co-infections and stressors as well as, the risk of bacterial shedding (Branton et al., 2002; Bwala et al., 2018; Ferguson et al., 2003; Ferguson-Noel and Williams, 2015; Gates et al., 2008; Hopkins, 2005; Kanci et al., 2018; Leigh et al., 2019; Mohammed et al., 2007; Zhang et al., 2018). Inactivated vaccines are efficient in prevention of respiratory diseases, prolonged in their action, minimizing disease transmission, reduce production losses and safer than live vaccines but, they are costly and difficult in their application and often need two repeated doses to be effective (Yoder, 1983; Ley, 2003; Ishfaq et al., 2020). Various adjuvants were used, but water in oil (w/o) emulsion Montanide ISA70 appeared recommended to be used in avian vaccinations (Cahyani et al., 2020; E1-Jakee et al., 2020). MG and MS inactivated vaccines that have had a sort of success, one or more purified antigens, killed pathogens, or bacterins with an oil adjuvant activate the immune response (Hildebrand, 1985; Rimler et al., 1978; Yoder, 1979, 1983). This study aimed to prepared and evaluate a local inactivated bivalent Mycoplasma vaccine including the following strains (MG and MS) to overcome such problems.

\section{MATERIALS AND METHODS}

\section{BACTERIAL STRAINS}

A locally isolated well identified MG and MS strains were obtained from Microbiology Department, Faculty of Veterinary Medicine, Cairo University, Giza, Egypt from a previous study by Marouf et al. (2020).

\section{VACCINE PREPARATION}

According to Bekele and Assefa (2018) the two strains were propagated for vaccine preparation as follow; MG and MS were cultured separately on PPLO broth and incubated at $37^{\circ} \mathrm{C}$ in $\mathrm{CO}_{2}$ incubator for 48 hours and colonies, the cultured bacteria were adjusted to contain $10^{8}$ colony forming unit/ $\mathrm{ml}$ in different groups of embryonated chicken eggs (ECEs) and hens was calculated using Rodwell and Whitcomb's standard techniques. Then, the bacteria were then pelleted by centrifugation at $5000 \mathrm{rpm}$ for 30 minutes at $4^{\circ} \mathrm{C}$. Then the bacteria inactivated with 0.3 percent formalin and agitation, the bacterial suspension was combined with Montanide ISA70 (SEPPIC ${ }^{\circledast}$, France) in a ratio of 71 adjuvant: 29 antigens according to (Charles et al., 1994). 


\section{EXPERIMENTAL BIRDS}

A total number of 50 specific pathogen free (SPF) chickens of one day old were obtained from SPF poultry farm at Koom Osheem Fayuom province, Egypt. They were housed in separate pens on deep litter system with fresh wood shavings as bedding on a concrete floor. Chicks were housed on adjusted conditions of temperature, humidity, ventilation and maintained on 24-hour constant-light system for 10 weeks observation period. They were kept in the same circumstances as previously reported by Evans et al. (2012). The birds received balanced ration (including starter, and grower ration) without any treatments and fresh clean water ad libitum previously presented by Burnham et al. (2002), that met or surpassed NRC (1994) recommendations. All birds were ascertained first to be free from Mycoplasma (antigens and antibody). All experimental conditions and birds handling procedures follow the instructions of Ethics Committee, Faculty of Veterinary Medicine, Cairo University.

\section{QUALITY CONTROL OF THE PREPARED VACCINE}

STERILITY TEST FOR OIL ADJUVANT AND TRIAL VACCINE The oil adjuvant (Montanide ISA 70) used in the vaccination was sterilized in a dray autoclave at $160^{\circ} \mathrm{C}$ for 1 hour. VF, Thioglycolat, Triptic soy broth, Tryptose agar, and Sabroud agar were used in sterility tests, which were incubated at $37^{\circ} \mathrm{C}$ for 7 days. To adequately emulsify the bacterial biomass, the Montanide oil adjuvant was admixed after validation of the growth inactivation process. The inactivated culture was further treated to assure its safety and sterility (Bekele and Assefa, 2018).

\section{Evaluation OF TRIAL VACCINE}

\section{EXPERIMENTAL DESIGN}

Fifty-day old SPF chicks were divided into five groups and sub-groups as summarized in Table 1.

Five groups of one day-old SPF chicks were reared separately. First Mycoplasma group (MG, MS) 20 bird were divided into 2 subgroups (10 bird for each strain) each subgroup was injected with $0.5 \mathrm{ml}$ (subcutaneous) S/C at mid neck region of the prepared inactivated Mycoplasma vaccine at 7 days old then boostered with another same dose and route after three weeks then each sub-group was challenged three weeks after the booster dose by eye dropping each strain (MG) and (MS) $0.5 \mathrm{ml}$ containing $10^{8} \mathrm{CFU}$ individually (Bekele and Assefa, 2018). Second challenged group for (MG) and (MS) group 20 bird will divided into 2 subgroups (10 bird for each subgroup) each subgroup was challenged three weeks after the booster dose of others by eye dropping each strain (MG) and (MS) $0.5 \mathrm{ml}$ containing $10^{8} \mathrm{CFU}$ individually. Fifth group containing 10 birds kept as blank control negative unvaccinated and unchallenged. After the challenge, the inoculated chicks were followed for 3 weeks. The severity of the clinical indications, mortality, and recovery of the challenge organisms from tracheal samples were used to determine the degree of protection. ELISA tests (ID Screen ${ }^{\circledR}$ Mycoplasma gallisepticum Indirect and ID Screen ${ }^{\circledR}$ Mycoplasma synoviae Indirect) were used to measure and evaluate the developed humeral immune response against MG and MS respectively based on the manufacture. Blood samples $(2 \mathrm{ml} /$ bird $)$ were collected from the wing vein before immunization, regularly after each vaccination, and post challenge for three weeks (once/week) to measure and evaluate the developed humeral immune response.

Tracheal samples and synovial fluid were collected before the start of the experiment and after challenge for a week (once/week) using sterile swabs inoculated into Saline from all chicks, vaccinated and control, and bacteriologically examined for Mycoplasma shedding.

\section{Purity TeST}

Testing of the manufactured vaccine for contamination by aerobic, anaerobic bacteria and fungi according to (OIE, 2012).

\section{SAFETY TEST}

The produced vaccine's safety was tested by injecting a double field dose $(1 \mathrm{ml})$ of the vaccine subcutaneously into each of 20 SPF chicks aged 2 weeks for two successive weeks, the chicks were monitored daily for any evidence of local responses, clinical symptoms, or mortality as mentioned by (OIE, 2012).

Table 1: Experimental design.

\begin{tabular}{|c|c|c|c|c|}
\hline Groups & $\begin{array}{l}\text { Sub- } \\
\text { group }\end{array}$ & $\begin{array}{l}\text { First vacci- } \\
\text { nal dose }\end{array}$ & Booster dose & $\begin{array}{l}\text { Challenged bacteria } \\
\text { ( } 3 \text { weeks after booster dose) }\end{array}$ \\
\hline \multirow[t]{2}{*}{ Bivalent Mycoplasma vaccine } & MG & \multirow[t]{2}{*}{ (7days old) } & \multirow{2}{*}{ (After 3 weeks) } & MG \\
\hline & MS & & & MS \\
\hline \multirow[t]{2}{*}{ Control positive challenged group } & MG & - & - & MG \\
\hline & MS & - & - & MS \\
\hline Control negative unvaccinated and unchallenged group & - & - & - & - \\
\hline
\end{tabular}




\section{Challenge TeSt}

Three weeks after immunization, all hens were challenged with a 24-hour broth culture of a field strain of (MG) and (MS). Each strain (MG) and (MS) was individually challenged by eye dropping $0.25 \mathrm{ml}$ containing $10^{8} \mathrm{CFU}$ of the challenge culture (OIE, 2012).

\section{RESULTS AND DISCUSSION}

\section{Clinical signs}

No clinical signs were observed in both vaccinated and control negative groups. The chickens in the control positive (MG) challenged group showed respiratory distress, coughing, sneezing, nasal discharge, and conjunctivitis. The chickens in the control positive (MS) challenged group showed retard growth and joints swelling and somewhat respiratory distress Figure 1.

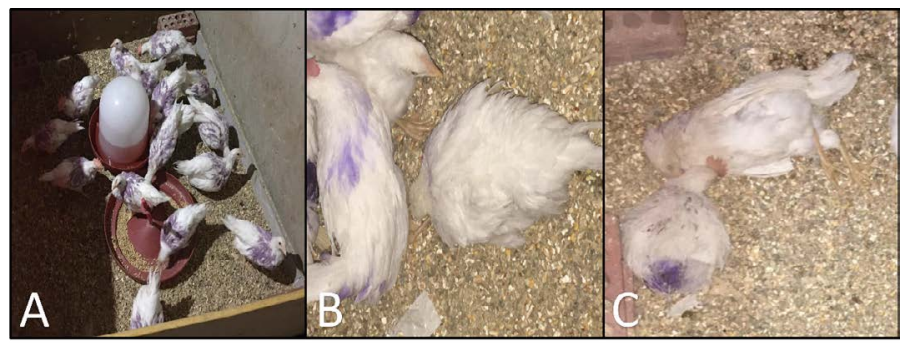

Figure 1: A, vaccinated and challenged group, showing alert apparently healthy chickens; B, Mycoplasma challenged group (control positive) showing chicken suffering from depression, unable to walk with ruffled feathers; C, dead chickens in control positive challenged group.

\section{MORBIDITY AND MORTALITY}

Low morbidities and mortalities were observed in both vaccinated and control negative groups. While the chickens in the control positive (MG) challenged group show high morbidity, high mortality, and chickens in the control positive (MS) challenged group reveals high morbidity, high mortality as seen in Figure 2.

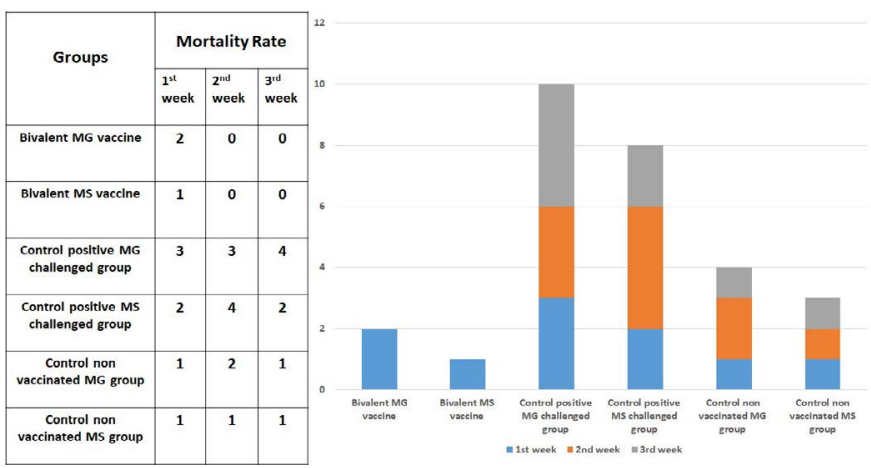

Figure 2: Mortality rate of chickens in different challenged groups.

\section{EVALUATION OF HUMERAL RESPONSE IN DIFFERENT} GROUPS

As illustrated in Tables 2 and 3, the geometric mean antibody titers against both $\mathrm{MG}$ and $\mathrm{MS}$ increased gradually to over the cut-off value $=843$ and 737 for both MG and MS respectively based on the interpretation of the used kits. The respective results give a good protective response for the bivalent MG/MS vaccine in overcoming the challenge by MG and MS.

\section{Detection of Mycoplasma SHEDDing}

Both MG and MS reisolated from tracheal swabs and synovial fluid in both control positive challenged group; on the contrary, the bivalent MG/MS group reveals no Mycoplasma shedding at reisolation.

Table 2: Geometric mean antibody titers against MG in sera of chicken vaccinated with bivalent MG/MS vaccine by indirect ELISA.

\begin{tabular}{|c|c|c|c|c|c|c|c|c|c|}
\hline \multirow[t]{3}{*}{ Intervals/groups } & \multicolumn{9}{|c|}{ Geometric mean antibody titers of MG } \\
\hline & \multicolumn{3}{|c|}{ Weeks post 1st vaccination } & \multicolumn{3}{|c|}{ Weeks post booster dose } & \multicolumn{3}{|c|}{ Weeks post challenge } \\
\hline & $\begin{array}{l}1^{\text {st }} \\
\text { week }\end{array}$ & $\begin{array}{l}2^{\text {nd }} \\
\text { Week }\end{array}$ & $\begin{array}{l}3^{\text {rd }} \\
\text { Week }\end{array}$ & $\begin{array}{l}1^{\text {st }} \\
\text { week }\end{array}$ & $\begin{array}{l}2^{\text {nd }} \\
\text { Week }\end{array}$ & $\begin{array}{l}3^{\text {rd }} \\
\text { week }\end{array}$ & $\begin{array}{l}1^{\text {st }} \\
\text { Week }\end{array}$ & $\begin{array}{l}2^{\text {nd }} \\
\text { week }\end{array}$ & $\begin{array}{l}3^{\text {rd }} \\
\text { week }\end{array}$ \\
\hline Bivalent MG/MS vaccine & 550 & 1050 & 1925 & 2325 & 2420 & 3150 & 2470 & 2950 & 3450 \\
\hline Control positive challenged group & 130 & 132 & 127 & 150 & 165 & 170 & 900 & 1500 & 1900 \\
\hline
\end{tabular}

Table 3: Geometric mean antibody titers against MS in sera of chicken vaccinated with bivalent MG/MS vaccine by indirect ELISA.

\begin{tabular}{|c|c|c|c|c|c|c|c|c|c|}
\hline \multirow[t]{3}{*}{ Intervals/groups } & \multicolumn{9}{|c|}{ Geometric mean antibody titers of MS } \\
\hline & \multicolumn{3}{|c|}{ Weeks post $1^{\text {st }}$ vaccination } & \multicolumn{3}{|c|}{ Weeks post booster dose } & \multicolumn{3}{|c|}{ Weeks post challenge } \\
\hline & $\begin{array}{l}1^{\text {st }} \\
\text { week }\end{array}$ & $\begin{array}{l}2^{\text {nd }} \\
\text { Week }\end{array}$ & $\begin{array}{l}3^{\text {rd }} \\
\text { Week }\end{array}$ & $\begin{array}{l}1^{\text {st }} \\
\text { week }\end{array}$ & $\begin{array}{l}2^{\text {nd }} \\
\text { Week }\end{array}$ & $\begin{array}{l}3^{\text {rd }} \\
\text { week }\end{array}$ & $\begin{array}{l}1^{\text {st }} \\
\text { Week }\end{array}$ & $\begin{array}{l}2^{\text {nd }} \\
\text { week }\end{array}$ & $\begin{array}{l}3^{\text {rd }} \\
\text { week }\end{array}$ \\
\hline Bivalent MG/MS vaccine & 456 & 890 & 1724 & 1980 & 2156 & 2890 & 2214 & 2750 & 3150 \\
\hline Control positive challenged group & 96 & 94 & 91 & 92 & 94 & 89 & 850 & 1350 & 1760 \\
\hline
\end{tabular}


ProteCTIVE EFFICACY OF THE PREPARED VACCINE

Following 3 weeks after the challenge, the manufactured vaccine had an $90 \%$ of $\mathrm{MS}$ and $80 \%$ of MG protection rate.

\section{DISCUSSION}

Studies on the frequency of Mycoplasma in Chicken indicated that Mycoplasma infection is a serious concern for chickens raised in commercial poultry industries (Bekele and Assefa, 2018; El-Ashram et al., 2021). Study after study has shown that Mycoplasma infections are not only common in commercial layer and broiler hens, but they are also common in backyard chickens in rural areas. Mycoplasmal infected birds usually showing signs of nasal discharge, synovitis, dyspnea with mouth breathing (rales), facial edema as well as gross postmortem lesions of congested lung, hyperemic mucoid trachea, and thickened air sacs (Talha, 2003). Where depopulation of animals is impossible, as on big commercial multi-age layer farms, increased mortality, carcass condemnation, and decreased egg production and hatchability are all costs linked with MG related illnesses (Ley,2008). So, vaccination is regarded the most practicable method of disease management (Bermudez and Kalbac, 1988).

From our results, a formaldehyde inactivated Montanide ISA70 based bivalent Mycoplasma vaccine was produced and tested in chickens using the ELISA technique and the tested vaccine gave protection to challenged chickens as neither mortalities nor clinical signs was observed in challenged chickens and provoked a protective antibodies level in chicken sera. These results are agreed with (Ferguson-Noel et al., 2012) as they confirmed that inactivated vaccinations against Mycoplasma can decrease vertical transmission, lower the severity of disease, and provide considerable protection for the respiratory system as well as the reproductive system. Also, Bekele and Assefa (2018) they found that Formaldehyde inactivated Montanide ISA70 based (MG) trial vaccine gave a protective level of anti $M G$ antibodies in chickens in Ethiopia. On the other hand, Evans et al. (1992) found that when SPF layer hens were vaccinated with an inactivated $M G$ vaccine and then challenged with a virulent $R$ strain of MG at 30 weeks, they showed substantial reductions in egg production. However, inactivated Mycoplasma vaccines give very modest protection against field strains and can minimize the shedding of MG organisms, but they are not able to inhibit the horizontal transmission between chickens. Some believe bacterins have a little role to play in the long-term protection of MG infection in commercial layer production facilities with different age groups (Jacob et al., 2014).

\section{CONCLUSIONS AND RECOMMENDATIONS}

The current research demonstrates that a locally manufactured inactivated bivalent Mycoplasma vaccine is safe and efficient against Mycoplasma infections and is recommended for application in poultry farm specially layers and breeders flocks to overcome these serious problems threaten poultry production in Egypt.

\section{NOVELTY STATEMENT}

The locally prepared inactivated bivalent Mycoplasma vaccine is a novel vaccine and revealed promising protection and recommended to be applied in poultry farms.

\section{AUTHOR'S CONTRIBUTION}

All authors share in the vaccine preparation, evaluation as well as, all authors share in writing and revising of the manuscript.

\section{CONFLICT OF INTEREST}

The authors have declared no conflict of interest.

\section{REFERENCES}

-Adler HE, McMartin D, Shifrine M (1960). Immunization against Mycoplasma infections of poultry. Am. J. Vet. Res., 21: 482-485.

- Beaudet J, Tulman ER, Pflaum K, Canter JA, Silbart LK, Geary SJ (2019). Immunologic pathways in protective versus maladaptive host responses to attenuated and pathogenic strains of Mycoplasma gallisepticum. Infect. Immun., 87: 613618. https://doi.org/10.1128/IAI.00613-18

- Beaudet J,Tulman ER, Pflaum K, Liao X, Kutish GF, Szczepanek SM, Silbart LK, Geary SJ (2017). Transcriptional profiling of the chicken tracheal response to virulent Mycoplasma gallisepticum strain Rlow. Infect. Immun., 85: e00343-17. https://doi.org/10.1128/IAI.00343-17

- Bekele L,Assefa T (2018). Inactivated vaccine trial of Mycoplasma gallisepticum in Ethiopia. Open J. Vet. Med., 8: 75-85. https://doi.org/10.4236/ojvm.2018.86009

-Bermudez AJ, Kalbac M (1988). Control of Mycoplasma gallisepticum infection in commercial layers: A field study. J. Am. Vet. Med. Assoc., 192: 1783.

-Branton SL, Bearson SM, Bearson B, Lott BD, Maslin WR, Collier SD, Pharr GT, Boykin DL (2002). The effects of 6/85 live Mycoplasma gallisepticum vaccine in commercial layer hens over a 43-week laying cycle on egg production, selected egg quality parameters, and egg size distribution when challenged before beginning of lay. Avian. Dis., pp. 423-428. https://doi.org/10.1637/0005-2086(2002)046[0423:TEOL MG]2.0.CO;2

-Branton SL, Lott BD, Deaton JW, Hardin JM, Maslin WR (1988). F strain Mycoplasma gallisepticum vaccination of post-production-peak commercial Leghorns and its effect on egg and eggshell quality. Avian Dis., 32: 304-307. https:// 


\section{doi.org/10.2307/1590817}

-Brown DR, Whitcomb RF, Bradbury JM (2007). Revised minimal standards for description of new species of the class Mollicutes (division Tenericutes). Int. J. Syst. Evolut. Microbiol., 57(11): 2703-2719. https://doi.org/10.1099/ ijs.0.64722-0

-Burnham MR, Branton SL, Peebles ED, Lott BD, Gerard PD (2002). Effects of F-strain Mycoplasma gallisepticum inoculation at twelve weeks of age on performance and egg characteristics of commercial egg-laying hens. Poult. Sci., 81: 1478-1485. https://doi.org/10.1093/ps/81.10.1478

- Bwala DG, Solomon P, Duncan N, Wandrag DBR, Abolnik C (2018). Assessment of Mycoplasma-gallisepticum vaccine efficacy in a co-infection challenge model with QX346 like infectious bronchitis virus. Avian Pathol., 47: 261-270. https://doi.org/10.1080/03079457.2018.1440064

- Cahyani JI, Widyarini S, Wibowo MH (2020). Comparative safety and efficacy of two bivalent vaccines containing Newcastle disease LaSota and avian influenza H9N2 Sidrap isolate formulated with different oil adjuvants. Vet. World, 13(11): 2493-2501. https://doi.org/10.14202/ vetworld.2020.2493-2501

- Charles CD, Rind D, Jouzel J, Koster RD, Fairbanks RG (1994). Glacial-interglacial changes in moisture sources for Greenland: Influence on the ice core record of climate. Science, 263: 508-511. https://doi.org/10.1126/ science. 263.5146 .508

-Eissa SI, Metwally AM, Hashem YM, Khalifa RA, Refaie MK (2014). molecular comparative analysis of mycoplasma gallisepticum field and vaccine strains in Egypt. Eur. J. Vet. Med., pp. 9.

-El-Ashram S, Hashad ME, Abdel-Alim GA, Abdelhamid TN, Deif H (2021). Seroprevalence of mycoplasmosis in broiler, layer, and native chickens in Giza, Egypt. PLoS One, 16(7): https://doi.org/10.1371/journal.pone.0254220

•El-Jakee KJ,Moussa IM, Omran MS, Ahmed BM, Elgamal MA, Hemeg HA, Mubarak AS, Al-Maary KS, Kabli SA, Marouf SA, Alhaaji JH (2020). A novel bivalent PasteurellosisRHD vaccine candidate adjuvanted with Montanide ISA70 protects rabbits from lethal challenge. Saudi J.Biol.Sci.,27(3): 996-1001. https://doi.org/10.1016/j.sjbs.2019.12.042

-Elyazeed HA, Al-Atfeehy NM, Abotaleb R, Sayed R, Marouf SH (2020). Preparation of ELISA and Lateral Flow Kits for rapid Diagnosis of Mycoplasma gallisepticum in Poultry. Sci. Rep., 10: 9056. https://doi.org/10.1038/s41598-02065848-7

-Evans JD,Leigh SA,PurswellJL,Jacob R,Peebles ED, Collier SD, Branton SL (2012). A comparative study of live attenuated F strain-derived Mycoplasma gallisepticum vaccines. Avian Dis., 56: 396-401. https://doi.org/10.1637/9951-092711Reg.1

-Evans RD, Hafez YS, Schreurs CS (1992). Evaluation of a Mycoplasmagallisepticum strain exhibiting reduced virulence for prevention and control of poultry mycoplasmosis. Avian Dis., 36: 197-201. https://doi.org/10.2307/1591490

- Fabricant J (1975). Immunization of chickens against Mycoplasma gallisepticum infection. Am. J. vet. Res., 36: 566-567.

-Ferguson NM, Hermes D, Leiting VA, Kleven SH (2003). Characterization of a naturally occurring infection of a Mycoplasma gallisepticum house finch-like strain in turkey breeders. Avian. Dis., 47: 523-530. https://doi. org/10.1637/6059
- Ferguson-Noel N, Cookson K, Laibinis VA, Kleven SH (2012). The efficacy of three commercial Mycoplasma gallisepticum vaccines in laying hens. Avian Dis. Jun., 56(2): 272-275. https://doi.org/10.1637/9952-092711-Reg.1

-Ferguson-Noel NM, Williams SM (2015). The efficacy of Mycoplasma gallisepticum $\mathrm{K}$-strain live vaccine in broiler and layer chickens. Avian. Pathol., 44: 75-80. https://doi.org/10. 1080/03079457.2015.1005054

- Gates AE, Frasca S, Nyaoke A, Gorton TS, Silbart LK, Geary SJ (2008). Comparative assessment of a metabolically attenuated Mycoplasma gallisepticum mutant as a live vaccine for the prevention of avian respiratory mycoplasmosis. Vaccine, 26: 2010-2019. https://doi.org/10.1016/j. vaccine.2008.02.010

- Hildebrand D (1985). Immunology and prophylaxis associated with the use of a Mycoplasma gallisepticum bacterin in chickens. Clin. Vet. (Milano), 108: 89-94.

- Hopkins B (2005). Biomune vaccines. Personal communication.

-Hussein A, El-Shaib TM, Saoud SM, Shalaby NA, Sultan H, Ragab AM (2007). Protective immune response of Mycoplasma gallisepticum vaccines in poultry. Egypt. J. Immunol., 14: 93-99.

- Ishfaq M, Hu W, Khan MZ, Ahmad I, Wenxin G, Li WJ (2020). Current status of vaccine research, development and challenges of vaccines for Mycoplasma gallisepticum. Poult. Sci., https://doi.org/10.1016/j.psj.2020.06.014

- Ishfaq M, Zhang W, Hu W, Shah SWA, Liu Y, Wang J, Wu Z, Ahmad I, Li J (2019). Antagonistic effects of baicalin on Mycoplasma gallisepticum induced inflammation and apoptosis by restoring energy metabolism in the chicken lungs. Infect. Drug. Resist., 12: 3075-3089. https://doi. org/10.2147/IDR.S223085

-Jacob R, Branton SL, Evans JD, Leigh SA, Peebles ED (2014). Effects of live and killed vaccines against Mycoplasma gallisepticum on the performance characteristics of commercial layer chickens. Poult. Sci., 93(6): 1403-1409. https://doi.org/10.3382/ps.2013-03748

- Kanci A, Wijesurendra DS, Wawegama NK, Underwood GJ, Noormohammadi AH, Markham PF, Browning GF (2018). Evaluation of Mycoplasma gallisepticum (MG) ts-304 vaccine as a live attenuated vaccine in turkeys. Vaccine, 36: 2487-2493. https://doi.org/10.1016/j.vaccine.2018.02.117

- Kleven SH (2003). Mycoplasma synoviae infection. In: Diseases of poultry, Saif YM, Barnes HJ, Glisson JR, Fadly AM, McDougald LR and Swayne D.E., eds. Iowa State University Press, Ames, Iowa, USA. pp. 756-766.

-Kleven SH (2008). Control of avian mycoplasma infections in commercial poultry. Avian Dis., 52: 367-374. https://doi. org/10.1637/8323-041808-Review.1

-Kleven SH, Glisson JR, Lin MY, Talkington FD (1984). Bacterins and vaccines for the control of Mycoplasma gallisepticum. Isr. J. Med. Sci., 20: 989-991.

-Leigh SA, Evans JD, Branton SL (2019). Complete genome sequences of two vaccine strains and one field isolate of Mycoplasma gallisepticum. Microbiol. Resour. Announc., 8: 01237-19. https://doi.org/10.1128/MRA.01237-19

- Levisohn S, Kleven SH (2000). Avian mycoplasmosis (Mycoplasma gallisepticum). Rev. Sci. Tech. Off. Int. Epiz., 19(2): 425-442. https://doi.org/10.20506/rst.19.2.1232

-Ley DH (2003). Mycoplasma gallisepticum infection. In: Saif, Y.M. (Ed.), Diseases of poultry, $11^{\text {th }}$ ed. Iowa State Press, Ames. pp. 722-743.

-Ley DH (2008). Mycoplasma gallisepticum infection. Disease of 
poultry. $12^{\text {th }}$ ed. Y.M. Saif, A.M. Fadly, J.R. Glisson, L.R. McDougald, L.K. Nolan and D.E. Swayne, ed Blackwell Publishing Press, Ames, IA. pp. 807-834.

- LuginbuhlRE,TourtellotteME,Frazier MN (1967).Mycoplasma gallisepticum control by immunization. Ann. NY. Acad. Sci., 143: 234-238. https://doi.org/10.1111/j.1749-6632.1967. tb27662.x

-Marouf S, Moussa IM, Salem H, Sedeik M, Elbestawy A, Hassan A, Hemegf Turki M, Dawoudb Aymen S, Mubarakb Hossam Mahmouda Roua Abdullah Alsubkig Ali $\mathrm{H}$. Bahkalib. (2020). A picture of Mycoplasma gallisepticum and Mycoplasma synoviae in poultry in Egypt: Phenotypic and genotypic characterization. J. King Saud Univ. Sci., 32: 2263-2268. https://doi.org/10.1016/j.jksus.2020.02.036

- Mohammed J, Frasca SJr, Cecchini K, Rood D, Nyaoke AC, Geary SJ, Silbart LK (2007). Chemokine and cytokine gene expression profiles in chickens inoculated with Mycoplasma gallisepticum strains Rlow or GT5. Vaccine, 25: 8161-8121. https://doi.org/10.1016/j.vaccine.2007.09.057

- NRC (1994). Nutrient requirements of poultry. $9^{\text {th }}$ Rev. ed. Natl. Acad. Press, Washington, DC.

- Office International des Epizooties (OIE) (2012). Salmonellosis in manual of diagnostic tests and vaccines for Terrestrial animals.

- OIE (2004). Avian mycoplasmosis. In: Manual of diagnostic tests and vaccines for terrestrial animals, $5^{\text {th }}$ edition.

- Rabie NS, Girh ZA (2020). Bacterial vaccines in poultry. Bull. Natl. Res. Cent., 44: 15. https://doi.org/10.1186/s42269019-0260-1

- Razin S, Yogev D, Naot Y (1998). Molecular biology and pathogenicity of mycoplasmas. Microl. Mol. Biol. Rev., 62: 1094-1156. https://doi.org/10.1128/MMBR.62.4.1094-
1156.1998

- Rimler RB, Davis RB, Page RK, Kleven SH (1978). Infectious coryza: Preventing complicated coryza with Haemophilus gallinarum and Mycoplasma gallisepticum bacterins. Avian Dis., 22: 140-150. https://doi.org/10.2307/1589517

-Rodwell AW, Whitcomb RF (1983). Methods for direct and indirect measurement of Mycoplasma growth. In: Razin S, Tully JG, editors. Methods in Mycoplasmology. $1^{\text {st }}$ ed. New York, NY: Academic Press, pp. 185-196. https://doi. org/10.1016/B978-0-12-583801-6.50036-6

-Talha AFSM (2003). Investigation on the prevalence and significance of $M$. gallisepticum in village chickens and possibility of establishing $M$. gallisepticum free flocks and significance of $M$. gallisepticum on different production parameters in layer chickens in Bangladesh. MSc thesis, The Royal Veterinary and Agricultural University, Denmark and Bangladesh Agricultural University, Mymensingh.

-Whithear KG (1996). Control of avian mycoplasmosis by vaccination. Rev. Sci. Tech. Off. Int. Epiz., 15: 1527-1553. https://doi.org/10.20506/rst.15.4.985

-Yoder HW (1979). Serologic response of chickens vaccinated with inactivated preparations of Mycoplasma gallisepticum. Avian Dis., 23: 493-506. https://doi.org/10.2307/1589580

- Yoder HW (1983). Laboratory studies with inactivated oilemulsion Mycoplasma gallisepticum vaccines. Avian Dis., 27: 339-340.

-Zhang D, Long Y, Li M, Gong J, Li X, Lin J, Meng J, Gao K, Zhao R, Jin T (2018). Development and evaluation of novel recombinant adenovirus-based vaccine candidates for infectious bronchitis virus and Mycoplasma gallisepticum in chickens. Avian Pathol., 47: 213-222. https://doi.org/10.10 80/03079457.2017.1403009 